Res Publica. Revista de Historia de las Ideas Políticas

ISSN: $1576-4184$

http://dx.doi.org/10.5209/RPUB.59700

\title{
Skinner's Methodology: A Weapon against Liberalism ${ }^{1}$
}

\author{
Gonzalo Bustamante Kuschel*2
}

Recibido: 25 de noviembre de 2016 / Aceptado: 11 de diciembre de 2017

\begin{abstract}
In this article, I suggest that it is plausible to argue that Skinner's methodology is inseparable from his intention to retrieve republicanism. This makes itself evident in the way he structures his critique of John Rawls. In line with Hobbes, this British historian interprets Rawls's A Theory of Justice as another example of theory being politically neutralized.

I will present the main aspects of Skinner's analysis of Rawlsian liberalism from a neo-Machiavellian perspective, and discuss to what degree this analysis is or is not conclusive vis-à-vis the relationship between Rawls and republicanism. Finally, I will assess to what extent it is ideology that motivates the British historian to put his methodology in line with republicanism.
\end{abstract}

Keywords: Skinner; Rawls; republicanism; Hobbes; Machiavelli.

\section{[es] La metodología de Skinner: Un arma contra el liberalismo}

Resumen. En este artículo, sugiero que es plausible argumentar que la metodología de Skinner es inseparable de su intención de rescatar el republicanismo. Esto se hace evidente en la forma en que estructura su crítica de John Rawls. El historiador británico interpreta la teoría de la justicia de Rawls, desde su diseño metodológico, como un ejemplo de un momento hobbesiano que busca neutralizar 'lo político' en la teoría. Presentaré los aspectos principales del análisis crítico de Skinner del liberalismo rawlsiano, especial atención existirá a la contraposición realizada por él entre una concepción neomaquiaveliana de la política versus una hobbesiana. Finalmente, se evaluará el papel conceptual que juega "histórical" en su metodología respecto de su mismo rescate del republicanismo.

Palabras claves: Skinner; Rawls; republicanismo; Hobbes; Maquiavelo.

Sumario: 1. Introduction. 2. Language and methodology in A Theory of Justice. 2.1. Methodological Critique. 2.2. Political Nature and Language. 2.3. Machiavelli's liberty versus Rawlsian law. 2.4. What is the relevance of this contraposition between "the old Machiavellian way of understanding liberty" and Rawls's "neo-Hobbesian" way? 2.5. The Hobbesian structure of "A Theory of Justice". 3. Rawls and republicanism. 4. Final remarks.

Cómo citar: Bustamante Kuschel, G. (2018). Skinner's Methodology: A Weapon against Liberalism, en Res publica 21.1, 109-122.

* Universidad Adolfo Ibáñez (Chile)

gonzalo.bustamante@uai.cl

1 Some of the ideas contained in this work have been presented previously in:

Conference: John Rawls, 40 años de Teoría de la Justicia UAI/UDP 12-13 de Noviembre 2011. Article: La crítica al modelo Rawlsiano de Quentin Skinner, Conceptos Históricos, diciembre, 2016, Argentina.

2 My gratitude to Carmen Oria for all her help with the English language translation of my original article. Also to my assistants Rodrigo Villalobos and María José Reyes. And to Malgorzata Lange for her help in editing this article. 


\section{Introduction}

According to Quentin Skinner, in the fifties, political philosophy found itself between Scylla -depoliticized philosophy reduced to the analysis of how language is used- and Charybdis, conservative theory that -through authors like Voegelin and Strauss - took on an anti-modern form. It is here where Skinner aims to create a history sufficiently attentive to its own politicization in order to reveal the context of political thought as well as to acknowledge the intentionality and ideological conflict by which all political discourse and social propositions arise. This is why Hobbes serves as a paradigm to show the use of rhetoric within the context of ideological battle whereby traditional linguistic elements are used in a different way and contrary to their original meaning. Thus, for Skinner", a merely "geometric and logical" examination of Leviathan would not take into account his reconfiguration of the Renaissance tradition or his anti-republican and anti-revolutionary, ideological intentionality. For Skinner, only an "in context" analysis and rhetoric can show the structuring of Hobbesian theory and reveal the intention of this contractual theory. The latter would help to replace the republican idea of freedom, depoliticize the citizenry and take sovereignty away from the people for the benefit of the State -a possible political agency ${ }^{-}{ }^{4}$.

My hypothesis is that Skinner's methodology is inseparable from his intention to redeem republicanism ${ }^{5}$. This becomes evident in the way he structures his critique of John Rawls ${ }^{6}$. A Theory of Justice is interpreted by the British historian -in line with Hobbes $^{-}$as another political neutralization of theory through a contractual a-priori construction which seeks to reduce the action taken by political agents to the mere enjoyment of their rights. According to Skinner, Rawls could be considered more of a Hobbesian as he appears to share this $17^{\text {th }}$ century philosopher's methodology and way of understanding things political.

In the following pages, I will firstly summarize the main aspects of Skinner's assessment of Rawlsian liberalism. For this purpose, the author of Visions of Politics refers to Machiavelli so as to express his critique of Rawls more clearly. This critique consists of three aspects: methodology, the nature of political language and the Hobbesian structure of $A$ Theory of Justice. Secondly, I will show to what extent his analysis is or is not conclusive with regard to the relationship between Rawls and

Q. Skinner, Reason and Rhetoric in the Philosophy of Hobbes, Cambridge, Cambridge University Press, 1997. As part of this strategy, Skinner provides an account of two central movements in Hobbes. The first one is the development of the idea of liberty, groundbreakingly different to that of the republic. The latter makes use of a theological vocabulary in order to reconfigure the idea of "representation" conceptually. That would explain the Hobbesian critique regarding the concept of the 3 "persons" of the Council of Nicaea, which is equivalent to producing 3 gods, and therefore three sovereigns. Hobbes's idea (applying L. Valla: cf. G. Paganini, "Hobbes, Valla and the Trinity" in British Journal for the History of Philosophy, 11, 2003 (2), pp. 183-218) is that there are three roles for persons but only one god. Hobbes's theological dispute is a political one. Today we would say: an ideological one. See: Q. Skinner, "Hobbes on Representation" in European Journal of Philosophy, Vol. 13 2005a (2), pp. 155-184 and P. Springborg, "Hobbes and Schmitt on the name and nature of Leviathan revisited", Critical Review of International Social and Political Philosophy 13, 2010 (2), pp. 297-315.

5 For a critical analysis of this project to revive republicanism from a "methodological" standpoint, cf. P. Springborg, "Republicanism, Freedom from Domination, and the Cambridge Contextual Historians", Political Studies 49, 2001, (5), pp. 851-876.

$6 \quad$ Skinner's critical assessment of Rawls focuses on his work published in 1971 and not on Political Liberalism published in 1993. 
republicanism. Finally, I will return to certain relevant aspects to contextualize the ideological intention that lies behind Skinner's critique of Rawls.

\section{Language and methodology in A Theory of Justice}

Skinner starts by analyzing Rawls's methodology in order to then conclude that this "erroneous view of the nature of politics" results in regulatory-policy approaches contrary to a republican theory.

\subsection{Methodological Critique}

Skinner takes on the word "historical" as a descriptive-normative criterion for evaluating any political theory. "Historical" implies that the use and meaning of language in a society are determined and legitimized by a network of conventions and linguistic practices. The logic of politics is a logic of ideological battle for defining these conventions through new linguistic uses.

This leads Skinner to consider political concepts as being tools for political acts of illocutionary speech through which reality is created intentionally ${ }^{7}$.

Hence the need to connect concepts with practice, institutions, traditions, and ideologies. Otherwise, there is no way of determining what it is exactly that they are challenging or what reality they are trying to defend or create.

Skinner's criticism of liberalism assumes that a central element of its political form is depoliticization, and contractualism is the means to achieve it $^{8}$. Hobbesian contractualism persists on the level of meaning, both of the concept and of the agents e.g. contracting individuals. In his view, the Hobbesian architecture would endure in liberal contractualism and would be reflected in its contemporary exponents ${ }^{9}$.

In the case of Rawls, Skinner believes that his first mistake is to confuse "rational" with "optimal". Rawlsian theory rests on the idea of rationality as being guided by the principle of self-interest. This means that if an agent is rational, then he/she seeks to satisfy his/her own interest to the highest possible degree. Thus, in the original position, the basic principles are determined by establishing what is "rational" with regard to those "interests". As with the idea of the 'invisible hand', the pursuit of this interest creates an ideal. For Skinner ${ }^{10}$, in contemporary theories, social freedom and individual liberty borrow from the idea of the 'invisible hand' the assumption that, if all the members of a society pursue their own self-interest in an enlightened

\footnotetext{
Q. Skinner, Visions of politics, Vol. 1, Cambridge, Cambridge University Press, 2002, p. 98.

8 Freeman, following Rawls, points out that the contract tradition of the author of A Theory of Justice is not Hobbesian; "Rawls remarks that he considers the works of Locke, Rousseau, and Kant to be definitive of the contract tradition: «For all its greatness, Hobbes’s Leviathan raises special problems» (TJ, 11n/10n rev.)”. Cf. S. Freeman, Rawls. Routledge, Texas, University of Texas, Austin, 2007, p. 4, note 3.

9 In the Schmittean tradition, one author which use a genealogical point of view to criticize from Hobbes the modern liberal conceptualization of political concepts is the Italian philosopher, Giuseppe Duso. Cf. G.Bustamante., "Duso's Critique of Political Philosophy: From Methodology to a Retrieval of Democracy" in Constellations: An international journal of critical and Democratic Theory. Online: Octubre 30. 2015. DOI: 10.1111/14678675.12187 ISSN: 1351-0487. ISSN: 1467-8675.

10 CF. Q. Skinner, The Foundations of Modern Political Thought, Vol. I: The Renaissance, Cambridge University Press, 1978 and Q. Skinner, The Foundations of Modern Political Thought, Vol. II: The Age of Reformation, Cambridge, Cambridge University Press, 1978.
} 
way, the outcome will be for the greatest general good of that entire society. For him, this (Rawls included) does not take into account that a characteristic of rationality is self-deception. The latter cannot be avoided, not even under the concept of the veil of ignorance. Self-deception leads agents to decide differently from what Rawls would expect and gives precedence to other principles - such as equality or security- over equal freedom for all and justice.

\subsection{Political Nature and Language}

In a different line of reasoning, for Skinner, Rawls's political structure is apolitical because the structure of rights prevails over the obligation of a citizen who seeks to ensure his/her own freedom. This apolitical character is a product of Rawls's methodology. According to Skinner, the voluntary and arbitrary declaration of a necessary normativity and the maximizing its application is apolitical as long as it does not take into account that conventions, and therefore intentions, are always contingent.

It is in this context that Skinner criticizes Rawls's idea of natural rights not only because they are understood ahistorically and apolitically, but because they are also used to protect individual freedom. While Skinner generally shares the objectives of Rawlsian policy with respect to freedom for all, he believes that the depoliticization of theory does not allow for a link between the possibility for all citizens to fulfill their own purposes and the need to understand civil obligations as a means to protect that freedom. Institutional protection originated from the original position and its subsequent contract of freedom as a primary good is not enough for it to be politically sustainable over time once that very same freedom is confronted with the factuality of the political world, and with actors very different from the rational agents shaped by the veil of ignorance in their decision-making.

The idea of 'protecting freedom' through a balance of rights would (in Skinner's opinion) be an expression of a Gothic tendency in Rawlsian thought.

As a consequence of the Rawlsian contract, the structure of rights would be a guarantee for the development of a liberal political system where, at the end of the day, the citizen would be a 'patient' of his/her freedom and not an agent of it. In keeping with Harrington in his work The Commonwealth of Oceana (here not much differently from Pocock), Skinner interpreted Gothic barbarism as a form of system for natural rights. In Skinner's view, the original sources are Grotius and Hobbes. In contemporary terms, this system of natural rights finds one of its main exponents in Rawls. Skinner points out:

The leader of this destructive movement has been Thomas Hobbes, whose Leviathan Harrington treats as the greatest monument to gothic barbarism [...] If we turn, for example, to such leading contemporary theorists as John Rawls, Robert Nozick and their endless disciples, we encounter a self-conscious attempt to revive and extend the same gothic vision of politics. The vision is one in which liberty is a natural right, the antonym of liberty is coercion, and the maximising of liberty is seen as the chief (perhaps the sole) duty of enlightened governments ${ }^{11}$.

11 Cf. Q. Skinner, Visions of politics, Vol. 1, op. cit., pp. 160-161. 
Rawls tries to revive Gothic liberty, which is understood as a natural right, coercion as its opposite, and the extension of the same liberty as the main task of an "enlightened" government.

In order to understand the implications of this project for Gothic liberty, according to the British historian, one must understand what it seeks to eradicate, in other words, what defined the wisdom of the ancient people that Harrington refers to. According to Skinner, Niccolo Machiavelli is the paradigmatic thinker of modern republican tradition. Without the Florentine philosopher, there would be no way of understanding the author of The Commonwealth of Oceana. Therefore, it is necessary to compare this author's project with that of the author of $A$ Theory of Justice.

\subsection{Machiavelli's liberty versus Rawlsian law}

In Skinner's reinterpretation, Rawls understood liberty as a 'fragile commodity' which must be protected from the principal danger that lies in wait: individualistic selfishness which can lead to everyone attacking the liberty of others. The danger lies in the nature of the rational agents who own liberty as a right ${ }^{12}$. Conversely, for Machiavelli who follows the Roman tradition, liberty is a status of independence or non-servitude vis-à-vis arbitrary will.

According to Skinner's interpretation of Machiavelli, law is not a sufficient guarantee of "freedom as non-domination" because the idea of "neutrality of law" or, if you wish, "a state of law that defends us all equally" is a misjudgment in that it does not notice that those who "legislate" will always do so in favor of their own interests. In that sense, a mixed government, according to Machiavelli, is not made up of abstract laws but of an active distribution of power between "those who want to rule (and not be governed) and those who do not want to govern, but [wish to] preserve their liberty (the many)".

\subsection{What is the relevance of this contraposition between "the old Machiavellian way of understanding liberty" and Rawls's "neo-Hobbesian" way?}

For Skinner, the problem is essentially political rationality. From the perspective of Rawlsian liberalism, the problem is reduced to finding a fair way of regulating our tendency towards self-interest; a consistent way (the fair way) would be to establish an impartial method for distributing rights between rational, competent agents and selfish ones, making it possible for every individual to possess the largest possible amount of rights within a system of liberties compatible with a system where there is an equal amount of liberties for all. On the contrary, the problem for Machiavelli is how to transform our natural inclination towards corruption into a virtuous concern for the common good of the political community.

\subsection{The Hobbesian structure of "A Theory of Justice"}

In Skinner's analysis of Rawls, the difference between Machiavelli's view and that of the author of $A$ Theory of Justice is that the latter considers liberty as part of a static distribution of equal natural rights for all, and law as the medium for conse-

12 Cf. Q. Skinner, Visions of politics, Vol. 1, op. cit., pp. 163-164. 
crating them, while Machiavelli sees liberty as a historical and social achievement that, according to Skinner, would completely collapse without the proper institutions and engaged citizens. Therefore, maintaining liberty involves looking at politics in its social, historical and ideological context which is characterized by conflict rather than consensus, and the latter - consensus- can only be a reflection of one group's hegemonic dominance ${ }^{13}$.

In his view, this neo-Roman liberty is a "formula" that creates institutions of a nature different from that of the Hobbesian one present in Rawls's work. This institutional design is defined by the question of non-dependence. Machiavelli's key question is not how to distribute rights but rather how to build a republic where no human being has to serve another. With this objective in mind, it is necessary for the law to protect the liberty granted to the people and for it to be protected by the people. This is reflected in Machiavelli's view regarding the acceptance and defense of judges and magistrates as an institution where the "many" can only be elected and the "few" excluded. What constitutes the guiding criterion for evaluating them is the capability of the ruling government to ensure that the republic is not corrupted, corruption being the loss of liberty that internally ends all political community. In order to safeguard liberties, the ancient wisdom represented by Machiavelli reminds us, in Skinner's opinion, that the main threat to freedom is the ruling elite and not the people. Corruption of the "few" is more likely than corruption of the "many". Hence, the need for law and constitutional order to create and support the active participation of the people in the affairs of the res publica. This marks a radically different understanding of the institutions in Machiavelli's neo-Roman republicanism and those in Rawls's A Theory of Justice.

\section{Rawls and republicanism}

Quite a few thinkers, such as Alan Patten ${ }^{14}$, have criticized Skinner's analysis of Rawls as a "one-sided reading", a description which - among other things- does not take into account relevant aspects of $A$ Theory of Justice. In Patten's view, Skinnerian republicanism argues that active citizenship is basically good because it makes it possible to preserve a free society. This places the British historian in line with "instrumental republicanism" which can be characterized by the statement that citizenship and public service help to bring about a Neo-Roman negative liberty.

According to Patten, Skinner claims that a republican's main pledge is to live in a "free state", which acts upon its own intentions, represents the common will of its own people, and where actions are not restricted. In his critical assessment of Skinner's thought, republicans have two different reasons for appraising free states. In the first place, one of the biggest strengths of free states is being able to achieve prosperity and civic greatness in comparison to unfree states. The second reason, and

13 Kari Palonen highlights the influence that existed in Cambridge when Skinner was formed by Marx and Mannheim in understanding “ideology". Cf. K. Palonen, Quentin Skinner. History, Politics, Rhetoric. Cambridge, Polity Press, 2003. On the other hand, Amartya Sen notes the influence (vía Sraffa) of Gramsci on the later Wittgenstein and his critique of this culture. Cf. A. Sen, "Sraffa, Wittgenstein, and Gramsci" in Journal of Economic Literature 41, 2003, (4), pp.1240-1255.

14 A. Patten, "The Republican Critique of Liberalism" in British Journal of Political Science 26, 1996, (1), pp. 25-44. 
the most important for Skinner, is that free states are superior at ensuring the personal liberties of their citizens than non-free states are capable of.

In Patten's view, according to republicans, the reasons why free states turn into unfree ones their citizens are disinterested and do not apply oversight, which leads to the central republican problem of not being able to identify the conditions needed in a society so that institutions can guarantee people's liberty in spite of the corruption within them. This is the main reason why republicanism justifies its emphasis on citizens being politically engaged: All people must participate actively in politics to secure a free society. The paradoxes arise for Patten because Skinner equates "free society" with the personal liberties "to be unconstrained from pursuing whatever goals we may happen to set ourselves"15. In that sense, for Skinner, this active participation should be considered a duty because the end of "be free" has priority over other particular or personal motives. According to Patten, this conflict of interests in Skinner does not find an answer; the only solution would be to appeal to fairness or to a Kantian moral framework, one that takes the original position -or a similar one- as a resource.

Furthermore, Patten points out that the personal liberties considered by republicans are also the same as some of the general negative liberties that liberals embrace, such as personal security and political liberties. Similarly, Charles Larmore ${ }^{16}$ defends the idea that the separation between a "liberal and republican form" of liberty is fictitious, and therefore wrong.

In a different way, this criticism is shared by Patricia Springborg ${ }^{17}$, who rejects the idea of "individual republican freedom" since the formula "freedom as non-domination" is typical of every slave society in which it is necessary to distinguish between "who is free and who is a slave". In that sense, according to Springborg, Skinner is the victim of the same anachronism that he tries to fight. Finally, another great figure of neo-republicanism, Pettit, seeks to build bridges with liberalism à la Rawls, which the latter (Rawls) considers plausible as "compatible". A more radical assessment is that of Martinich ${ }^{18}$ who claims that Skinner's mistake is more general, namely, that he does not understand (and therefore incorrectly uses) the various forms of "meaning".

Others, like Miguel Vatter ${ }^{19}$, argue that, if one looks at his idea of "representation", Rawls is not a "liberal" but a "republican". In his non-Hobbesian reinterpretation of representation, the author of $A$ Theory of Justice oscillates between Lock's and Kant's ideas. While the former philosopher allows a right of resistance on non-corporativist assumptions in relation to the people and their power, the latter rejects a contract of subjection. Both aspects are present in Rawls's work. According to Vatter, when Rawls says that any conception of political justice "is always subject

15 A. Patten, "The Republican Critique of Liberalism”, op. cit., p. 28.

16 C. Larmore, The Morals of Modernity, Cambridge, Cambridge University Press, 1996.

17 P. Springborg, "Republicanism, Freedom from Domination, and the Cambridge Contextual Historians" in Political Studies 49, 2001, (5), pp. 851-876.

18 A. Martinich "Four Senses of «Meaning» in the History of Ideas: Quentin Skinner's Theory of Historical Interpretation" in Journal of the Philosophy of History 3, 2009, (3), pp. 225-245

19 Cf. M. Vatter, "Il potere del popolo e la rappresentanza in Rawls en el repubblicanesimo cívico" in Filosofia Politica 2 (2010), pp. 263-286 and M. Vatter, "Republicanism or Modern Natural Right? The Question of the Origins of Modern Representative Democracy and the Political Thought of Giuseppe Duso" in The New Centennial Review 10, 2010, (2), pp. 99-120. 
to being checked by our reflective considered judgment"20, by "reflective judgment" Rawls, in a technical sense, is referring to a Kantian idea of judgment that does not subsume "under a given universal norm (this is determinative judgment), but seeks out, from the particulars, the corresponding principles" 21.

This is why republican authors desert the medieval corporativist concept of the people and instead accept Hobbes's essential proposal that civil association must begin with the people.

On the other hand, Philip Pettit ${ }^{22}$ seeks to revive republicanism as an alternative to liberalism which now reigns supreme. He argues that essential to this is the idea of freedom as "non-domination", thus not as a different variety of negative freedom but as a kind of freedom with a qualitative difference. The key to Pettit's political design is the need for the law to act as a guarantor of freedom. The rule of law would be the space for "interference that does not generate domination" (non-mastering interference). Pettit's critical assessment of Rawls ${ }^{23}$ is less radical than Skinner's. To believe that the only thing justice demands from a society's citizens is equal freedom as non-domination is unimaginable given John Rawls's theory of justice which is determined by two principles; one that establishes equal freedom and another that is related to material equality. In Pettit's words: "First, unlike the republican approach, Rawls's first principle does not require full resourcing for the basic liberties; and, second, it does not require their protection against domination, only their protection in a weaker sense" 24 .

According to Pettit, from Rawls's viewpoint, people have the liberty to do or not do anything they want as long as it is legal for them to do or not do so, and their decision is a legally respected right. The ability to choose is not necessary for the concept of liberty alone, but rather for its own account. Thus, as for Rawls's first principle, public resourcing does not have to safeguard everyone's decisions, deemed as basic liberties. The principle also dismisses the republican prerequisite because it does not uphold the preservation of basic liberties with the same degree of safeguarding. In accordance with common habits, Rawls presumes that since people are supposed to have a constitutional obligation that keeps them from hindering others' basic liberties, they are constrained by sanctions.

Therefore, even though sanctions can regularly assure people that others will uphold their legal obligations, in Rawls's ideal system of collective compliance, these sanctions are not necessary and do not have to be enforced. This explains why, for Rawls, domination is not a problem in itself because society, according to his theory, can be efficient and organized as the authorities seek the common good. In Pettit's view $^{25}$, establishing penalties just to provide certainty that people's liberties will be respected may not prevent the abuses committed by the powerful. He asserts that Rawls's theory takes Kant's lead in creating some type of criteria in order for a common organization to be widely accepted by claiming that his two principles would have been called upon in an initial state of contract by which people perform without

\footnotetext{
J. Rawls, A Theory of Justice, Cambridge University Press, 1995, p. 193.

M. Vatter, "Devices of Representation and the Power of the People in Rawls and in Civic Republicanism" in APSA Annual Meeting, Boston, EEUU, August, note 13.

P. Pettit, Republicanism: a theory of freedom and government, Oxford, Oxford University Press, 1991.

P. Pettit, On the People's Term, Cambridge, Cambridge University Press, 2013.

P. Pettit, On the People's Term, op. cit. p. 107.

P. Pettit, On the People's Term.
} 
knowledge of their own place in the social order. Later on, he continues under the same proposition when he expands the criteria for constitutional qualification to include a test of civic justifiability whereby the social order is legitimized because the citizens justify and accept it.

It is not the intention of this article to give an account of these criticisms. However, it seems appropriate to point out that some of them are either attempts to reconcile "liberalism" and "republicanism" or elaborations of Pettit's republicanism questioning Rawls's assertions while others are based on a misunderstanding of how inseparable Skinner's methodology is from his republican ideology.

First, from a strictly historical perspective, it is possible to identify a tradition that considers the foundation of politics not as something based on the ideology of natural law, where freedom is guaranteed by the "rule of law", but rather as something based on civic participation, civic virtue, self-determination and objection to power by those who "non-govern". This tradition has been known as "republicanism", which in the Anglophone tradition (to which Skinner belongs) has been described by Pocock $^{26}$, Gordon Wood ${ }^{27}$ and Bailyn ${ }^{28}$; and theorized by Arendt ${ }^{29}$ and Pettit ${ }^{30}$ most prominently.

In relation to this, although it may be noted -in keeping with Kalyvas and Katznel$\operatorname{son}^{31}$ - that liberalism emerges as an evolution of republicanism, this does not deny the difference but rather explains the evolutionary genesis that produces two different ways of looking at politics, power, citizenship and freedom.

In Skinner's interpretation, Rawls's methodology in A Theory of Justice is essentially Hobbesian, but it is perhaps better to describe it as a Hobbesian methodology which seeks to obtain an eminently Kantian result that converges in A Theory of Justice. In Rawls's contractualist structure, both traditions come together. On the one hand, there is the assumption that freedom à la Hobbes does not solve the conflicts between private interests and the collective good, as maximizing our individual freedom involves maximizing the area of immunity from interference for the general welfare and therefore, by the same token, cannot provide a general guarantee that the basic general interest will be safeguarded to the maximum. Others, like Kant, see liberty as the ability of individuals to self-determine in an a-priori manner and in such a way that their will does not depend on facticity, but instead is their legislator.

Therefore, the factual part of social reality should be governed by the principles that autonomous reason is able to determine. This becomes evident if one looks at the definition of law in Kant. According to Rawls, what one should do is to combine both traditions (Hobbes-Kant) in order to obtain a Kantian type of result. Even though he contemplates something that is present in Hobbes, namely that individuals are basically selfish agents, he tries to neutralize this aspect through the veil of ignorance in order to transform the same selfishness into an incentive for obtaining universal

26 J.G.A. Pocock, The Machiavellian Moment: Florentine Political Thought and the Atlantic Republican Tradition, New Jersey, Princeton University Press, 1975.

27 G. Wood, "Classical Republicanism and the American Revolution", in Chicago-Kent Law Review, Vol 66, 1990, Issue 1. Available at: http://scholarship.kentlaw.iit.edu/cklawreview/vol66/iss1/3 and G. Wood, The Radicalism of the American Revolution. New York, NY, Vintage Books, 1991.

28 B. Bailyn, The Ideological Origins of the American Revolution, Harvard University Press, 1967.

29 H. Arendt, On Revolution. New York, Viking, 1963.

30 P. Pettit, Republicanism: a theory of freedom and government, Oxford, Oxford University Press, 1991.

31 A. Kalyvas and I. Katznelson, Liberal Beginnings: Making a Republic for the Moderns. Columbia University, New York, 2008. 
principles in accordance with Kant's structuring. The veil of ignorance allows him to reach his own result of Kantian normativity from the initial starting point of Hobbesian individuals.

In this sense, Skinner aims to recapture a historical political tradition that is indeed different from the predominant liberal tradition. His approach is different from that of Pettit who, in a historical post-rescue way, seeks to create a systematic interpretation of "republicanism" that competes with liberalism within the normative tradition of political philosophy. Therefore, to project some of Pettit's criticism onto Skinner does not seem appropriate. My thesis is that Skinner's methodology follows a "republican path".

Regarding this point, this paper has already shed some light on the work of Palonen $^{32}$, one of the keenest students of Skinner and Koselleck, who suggests that:

1. "Historical" is a normative criterion in Skinner's theory.

2. The reappropriation of Austin Skinner's theory of "meaning" cannot be separated from a political interpretation (understood as action) of the history of philosophical and political thought.

3. As a result of the above, Skinner's theory of speech acts implies an understanding of politics as "intrinsic activity", which is performative by nature.

4. Political concepts (e.g. liberty) do not exhaust their meaning in their "descriptive meaning". Their meaning always involves linguistic actions.

5. There is a contingent-performative predominance over political theorization which does not mean reducing the latter to simple facticity that gains legitimacy through ideology in an an instrumental way.

Even though Palonen -in his description of and assumptions about Skinner- addresses a number of other points, based on those mentioned above, we can detect how the British historian's methodology is inseparable from his project to revive the republican tradition. If Laslett ${ }^{33}$ considered political philosophy as "dying or dead" because of an analytical philosophy and this, in turn, coincided with the interpretation of the "end of ideologies" which is the result of a liberal hegemony; to challenge the latter would have required a theory that was not captured by the same conditions that made political philosophy irrelevant as a means of understanding the "political" and the advancement of liberal hegemony.

From an intellectual perspective, the latter would be directly linked to Skinner with the emergence of the new Hobbesian science, and its contractual and deductive structuring. We can only understand Skinner's criticism of Rawls if we realize that the latter's methodology is a product of this new Hobbesian science. Or, to put it another way, that it does not contain sufficient elements to complete the required splitting of the two and, instead, there is a latency and presence of a significant continuity.

Similarly, for methodological reasons that are inseparable from a political vision, Skinner does not take into account that Rawls was drawn to Kant's interest in inter-

\footnotetext{
32 K. Palonen, Quentin Skinner. History, Politics, Rhetoric. Cambridge, Polity Press, 2003 and K. Palonen Die Entzauberung der Begriffe: Das Umschreiben der politischen Begriffe bei Quentin Skinner und Reinhart Koselleck. Münster, Lit-Verlag, 2003.

33 P. Laslett, Philosophy, Politics and Society. London, Oxford, Basil Blackwell Press, 1956.
} 
preting Roman law ${ }^{34}$. One can plausibly assume that this is due to the simple fact that Kant does not belong to the Anglophone tradition which is what the British historian especially - but not exclusively- focuses on with regard to republicanism. But also, because the republican elements present in Kant, such as the influence of Roman law, are incorporated into a framework in which political action is understood as inextricably linked to a morality that is determined a priori; it is also a aprioristic approach. Even the idea of a "republican constitution based on a principle of freedom" would involve a horizon in the form of a policy model and which additionally would subordinate action to the normativity of the moral principles shared aprioristically -not historically - by individuals who have autonomous rationality. That same Kantian autonomy would imply the possibility of conditioning, judgment and political decision pre-factually.

That is why -despite Rawls's Kantian, non-Hobbesian elements- Skinner nevertheless takes a critical view of his methodology. Both in Hobbes and Kant, contractualism and rational structure are more relevant than the influence of Roman law. In his analysis, Skinner ponders what brings them closer and ultimately makes them "representatives of modern liberal tradition", namely the predominance of a model that deems it possible to determine politics a priori and in a rational manner.

In the case of Hobbes, his theory includes materialistic mechanism which renders possible the creation of a human psychology whereby a common experience is eclipsed by the subjectivity of individuals who only experience themselves. In the case of Kant, it is the confidence in a positive anthropology about both the possibilities of autonomous reason, which morally regulates individuals, as well as an idea of history itself which involves not only a material but also a moral and political progress. Linguistic apparatuses that describe a system of rights - which, in the end, would be of a Gothic type- can be created based on various anthropological models.

Therefore, if the category "republican" is adequate for Kant and Rawls, then it would be different, in meaning and consequences, to the neo-Roman type described in Machiavelli and the tradition of English republicanism. It would involve taking a word and reconfiguring its meaning; it would be understood as "republican", which is a form of liberalism.

The republican tradition in Skinner's methodology may be detected if one focuses on the performative character that underlies both language and the idea of freedom, citizenship and representation in the republican tradition. This performative reality should be reflected in a permanent action by political actors. That is, the idea of a "passive citizenship" and a right that is "passive and immutably protects" implies a lack of understanding of the fact that the linguistic logic of politics is -in the endidentical to that of war, only with a different grammar.

If politics happens through the use of concepts and linguistic realities are wielded as weapons, how does this affect the reading of natural liberal law as well as Hobbes's and Rawls's contractarian methodology? With regard to the ontology that underlies it, in Skinner's view, Machiavelli is a paradigmatic example of how to understand the ontology of politics.

34 Regarding the connections of Kant and Roman Law, cf. A. Ripstein, Force and Freedom: Kant's legal and Political Philisophy, Harvard University Press, 2009 and R. Maliks, Kant's Politics in Context, Oxford University Press, 2014. 
What is the definition of this ontology? The desire of a few to dominate others using an economy of violence as a weapon, that is, using language rather than physical force. This linguistic domination always takes over law and discourses that validate the state itself. Therefore, Skinner's methodology, more than being influenced by Austin, Searle or Geertz, can be read as a "modernization" of Machiavelli's methodological proposal -along with the anthropology and social ontology that lies behind it - in order to rescue a neo-Roman republican theory from oblivion, one that is able to compete with the very same liberalism that sent it into oblivion.

\section{Final remarks}

In authors such as Skinner, the reconstruction of contemporary republicanism is articulated on the basis of interpreting liberty as being bestowed with an agonal nature. It is precisely this agonistic structure which enables Skinner and his republican theory to overcome liberalism's apolitical character in a return to a political one. While "liberal pluralism" is built on the notion of consensus anchored in laws as a guarantee of immunization against risks - an immunity which annuls the need for politics - republicanism assumes that those two humors described by Machiavelli are permanent over time and, therefore, the struggle between them in a society made up of free men is carried out by means of words and rhetoric.

Skinner's methodology presupposes a theory of acts of speech as well as rhetoric. From his viewpoint, an analysis of rhetoric allows for a deeper understanding than analytic philosophy or philosophical hermeneutics. Skinner found a more effective method for socio-political criticism in Renaissance rhetoric rather than philosophical analysis. This rhetoric manifests the controversial nature of political and social thought.

By analyzing the use of paradiastole ("rhetorical redescription") and political statements, Skinner sought to unravel the linguistic context in which social praxis is created. Skinner defines paradiastole as:

Henry Peacham in the first edition of his Garden of Eloquence accepts that paradiastole is "nye kin" to meiosis, but treats the latter as referring to the general technique of using "a lesse word for a greater, to make the matter much lesse then it is". By contrast, he reserves the term paradiastole -in a clear allusion to Susenbrotus- for cases in which "by a mannerly interpretation we doe excuse our own vices, or other mens whom we doe defend, by calling them virtues ${ }^{35}$.

Skinner's methodological proposal and use of the paradiastole and speech acts enabled an analysis based on the use of ideas rather than content; like Nietzsche, he understood contents as manifold, depending on when and by whom they are used. He attacked the philosophical claim, especially from analytic philosophers, of legitimacy over certain concepts.

Another aim of Skinner's methodology was to show the meaning and conceptual structure of political speeches through the combination of rhetorical and linguistic 
analysis. He used paradiastoles to provide an explanation for the processes of re-describing and subverting the emergence of ideologies.

Skinner focused on the discursive use of concepts as political tools. This approach enables us to depersonalize socio-political speeches immersed in determined contexts, thus creating a better understanding of them in terms of their explanatory power and their capacity to generate a social reality. The reason why a certain author might advocate a given idea of freedom is better understood by specifying the linguistic and social conditions that enable various actors at certain times to defend particular concepts (e.g. "freedom") and assign certain contents. Using networks of meaning, Skinner explained that socio-political actions are not (at least not exclusively) determined by the socio-economic conditions of a factual political action but conditioned by a set of linguistic conditions which are, in turn, historically determined. Thus Skinner's criticism of authors such as Rawls and Habermas who, in his opinion, seek to create abstract and universal conditions for validating political and social life solely from an ethical perspective without taking into account that political language is immersed in a historical period and that it aspires to impose ideologies rather than reach a consensus or establish ethical regulations.

Republican rhetoric ${ }^{36}$ links the possibilities of collective, practical reasoning with those of public norms and ideas which act as a common ground facilitating collective action through an audience who judges which reason is the best. In the case of autonomous institutions, republican rhetoric signifies political deliberation. This is what Llanque (2005) describes as "republican rhetoric", distinguishing it from that which only seeks approval through acclaim. Not the kind of audience who applauds but rather one that acts. For Skinner, with the rise of liberal liberty starting with Hobbes, there was a paradigm shift: from rhetoric to the simple eloquence of applause. This reversal of how a free political order was interpreted became possible through a process by which non-interference replaced the idea of non-domination and whereby the guarantees provided by the State -duly ensuring the necessary peace to achieve prosperity- replaced rhetoric as a means of deliberation with one geared towards legitimizing the self-same State.

In a 2007 interview published in Espace Temps.net ${ }^{37}$, Quentin Skinner said this about his differences with Rawls:

I knew Rawls only slightly, although we were colleagues for a year at Princeton and I admired him very much. If I look like a follower, it is mainly because he seemed, in his later writings, to adjust his earlier accounts of freedom and citizenship in such a way as to bring them closer to the kind of neo-Roman analysis I have just laid out. I have a number of doubts, however, about Rawls's approach to political theory via a theory of justice. One is that, if the political process is seen essentially as a means to ensure distributive justice, this tends in effect to produce a kind of juridification of politics. The practical result is that everything has to be settled in the law courts in the last resort, which in fact is what seems increasingly to be

36 Cf. M. Llanque, Republican Rhetoric as a Theory of Political Deliberation. Online: http://www.redescriptions. fi/media/uploads/yearbooks/2005/Llanque_05.pdf. 11/01/2018. Print: 2005.

37 J. Levy and E. Tricoire, "Quentin Skinner's Interview”, EspaceTemps Site, Fall 2007. Available at http://www. espacestemps.net/articles/quentin-skinner/ 
happening in the United States. It is this way of conducting civil society, I think, which increasingly looks like a kind of low-level civil war.

In other words, while Skinner recognized that Rawls somehow tried to adjust his stance on political liberalism to move closer to neo-Roman tradition, this effort did not suffice and furthermore did not serve to minimize Skinner's criticism over the possibility and pretentions of arriving at a political theory modeled on "a theory of justice". What this criticism points to is that it is precisely in methodological terms where a theory of justice takes on a Hobbesian structure.

My hypothesis is that those who have accused Skinner of having a "one-sided reading of Rawls" have not taken into account the following, at least not sufficiently: For the Cambridge historian, there is a connection between a methodology which implies a vision of how to interpret things political and the accompanying struggle between ideas, and the project to retrieve republicanism. Machiavellian republicanism could provide the tools to ponder the concepts of liberty and power without resorting to a theory of natural right to uphold that liberty but rather by exclusively applying the logic of politics. This of course does not mean that Skinner's theory is conditioned by his sympathy for republicanism. Neither does it mean that those who do not share that republican ideal cannot apply his methodology as, in point of fact, they do.

To a certain degree, Skinner's idea of what is political makes him akin to Arendt whose methodological approach to modern politics also sought to retrieve republicanism. The question remains as to what extent this very same republican theory might perhaps be in need of some rethinking based on a theory of natural right different from that of the liberal version, and whether Skinner's work opens up those possibilities or not. That subject would need to be addressed in another work and is not the objective of this one. 